IRA-International Journal of Management \& Social Sciences

ISSN 2455-2267; Vol.05, Issue 01 (2016)

Pg. no. 37-46

Institute of Research Advances

http://research-advances.org/index.php/RAJMSS

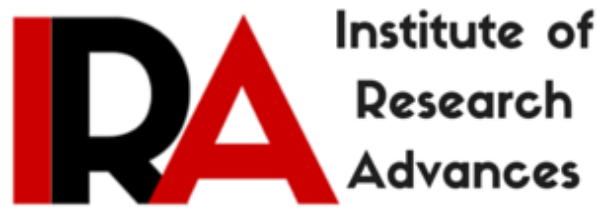

\title{
Volatility and Institutional Investors: A Sectoral Analysis of Indian Companies
}

\author{
${ }^{1}$ Harendra Singh \\ Asst. Professor \\ Amity Business School \\ Amity University, Madhya Pradesh, India. \\ ${ }^{2}$ Prof (Dr.) Anil Vashisht \\ Director \\ Amity Business School \\ Amity University, Madhya Pradesh, India. \\ ${ }^{3}$ Dr. Tripti Tripathi \\ Asst. Professor \\ Amity Business School \\ Amity University, Madhya Pradesh, India.
}

Type of Review: Peer Reviewed.

DOI: http://dx.doi.org/10.21013/jmss.v5.n1.p5

\section{How to cite this paper:}

Singh, H., Vashisht, A., \& Tripathi, T. (2016). Volatility and Institutional Investors: A Sectoral Analysis of Indian Companies. IRA-International Journal of Management \& Social Sciences (ISSN 2455-2267), 5(1), 37-46. doi:http://dx.doi.org/10.21013/jmss.v5.n1.p5

(C) Institute of Research Advances

(cc) BY-No

This work is licensed under a Creative Commons Attribution-Non Commercial 4.0 International License subject to proper citation to the publication source of the work.

Disclaimer: The scholarly papers as reviewed and published by the Institute of Research Advances (IRA) are the views and opinions of their respective authors and are not the views or opinions of the IRA. The IRA disclaims of any harm or loss caused due to the published content to any party. 


\begin{abstract}
There is a great deal of disarray with respect to different scholars about the relationship between the volatility and the institutional holdings pattern. The deciding variable is very vague and the precedence pattern is also not known. This relationship is consistent with two stories that either riskier asset attracts the institutional investors or the increment in the institutional holding result in the increase in the volatility. This research is directed towards finding the precedence and the sector wise impact of the institutional holding pattern.
\end{abstract}

Keywords: FIIs, Insurance, Mutual funds Regression, Quarterly volatility

\title{
Introduction
}

Till 1980's the economy of India was reserved for any kind of foreign investment but reforms where mooted after the relaxation that foreign inflows are very crucial for 360 degree development to prevail in India and to augment economic growth. This result in economic reforms that also encircled the capital market. As a sequence of matter there was a great deal of activity in the stock market the study aims at the effect on and the extent of the volatility in the stock market as per the prevailing institutional holding patterns.

There are important implication in economics and finance, in regards of the calculating the volatility in the equity market. Sometimes there is negative effects in the economy because of high level of volatility in the stock price and can also effect the decision of the investors that can affect any kind of inflow from the foreign as well as from the domestic investors. In the last decade all kinds financial crisis has led to the decline in the financial asset price volatility and thus undermine the financial stability. There is an empirical proof that the financial stability is in danger due to faster shift in the volatility rather than by any kind of sustained increase in the level of the volatility.

The movements in the stock prices are influenced by the flow of market information are well known to everyone and movement in other stock market can be one source. In contemporary world of today because of trading mechanism and investment patterns there can be information spillover of one market to another. Therefore the returns in different markets may affect each other. Economies are becoming dependent and are integrating themselves to the world economy because of higher degree of openness in the economies. All the decisions of portfolio investment are taken embedding the information relating to these price movements and volatility as regards assets traded. This can lead to reducing or gaining out of diversification across border investment in portfolios. The market traders have resorted to hedging, regulatory and portfolio strategies, for this reason they have to holistically understand the behavior of the market in the global context. This scenario has led to increased capital flows from FIIs to emerging economies like India with expanding stock market.

Here is a remarkable change in the nature, pattern and structure of the investment made by these FIIs. There are diverse view of FIIs investment in emerging economies in general and India in particular; one view is that FIIs are believed to improve market efficiency and helps in lowering the cost of capital the other view holds FIIs responsible for increasing the volatility in stock markets. India is considered as a good investment center after the restrictions are lifted in a liberalized regime. There has been increase in the capital flows into the country

It is a fact that institutional investor are very adept in their investment portfolio but even then those stocks in which they invest tend to show great deal of volatility but as per there specialization they avoid those stock which are highly uncertain and are very volatile and prefer those stocks that are stable in their returns than why it is that when these institution invest in the stocks they start showing volatility.

This is the target of the research that is volatility is a random phenomenon or institutional holding play a great role in unleashing it. 
The objective of the research is to see the sector and quarter wise impact of institutional holding pattern on stock volatility and to identify the relationship between stock market volatility and institutional holding patterns.

The period of study we took ranges from 1-jan-2008 to 30- sep-2014. The data was taken quarterly basis i.e. we have covered 26 quarters. The reason for taking this much of data was to know the wide scope of any FII flow on the volatility of the market, there has to be an extensive study on the various movements in the market spread over a wider range of time period.

\section{Literature review}

(Rai \& Bhanumurthy, 2004) had done an intensive study to find out the determinant responsible for the flow of FII and degree on impact. With the help of monthly data they found out that FII inflow depends on stock market returns, inflation rates (domestically as well as foreign), and ex-ante risk. In terms of the magnitude, the impact of returns on stock market and the ex-ante risk turned out to be the major determinants of FII inflow. The study has not found any causative link running from FII in the stock returns.

(Mehta, 2009) explained that The Indian stock markets have been experiencing humungous amount of FII flows. And it has affected small investors thinking that marketers are rigged. For the good news to Indian investors it has been established that out of all the factors, it is basically the performance of Indian stock markets vis-a-vis other emerging and developed markets that probably may cause returns and not the other way round.

(Agarwal, 1997) found that in that equity return has positive and significant effect on the FII. But given the huge volume of investment, foreign investor, foreign investor could play a role of market makers and book their profits i.e. they can buy financial asset when the price are declining thereby increasing the asset price and sell when the asset price are increasing. Hence there is possibility of bi directional between FII and equity.

(Douma, George, \& Kabir, 2006) Investigate the impact of foreign institutional investment on the performance of emerging market firms and founded that there is a positive effect of foreign ownership on firm performance. And also found impact of foreign investment on the business group affiliation of firms.

(Dahlquist, Pinkowitz, Stulz, \& Williamson, 2003)Analyzed ownership of foreign and characteristics of the firm for the Swedish market and found that foreigners mostly show their presence in large firms, firms paying low dividends and in firms with large cash holdings and also explained that firm size is driven by liquidity and measured international presence by foreign listings and export sales and reiterated that foreigners tend to underweight the firms with a dominant owner.

(Bansal \& Pasricha, 2009) Analyzed that there is change in market returns and volatility after the entry of FIIs in to Indian capital market and found that while there is no significant change in the Indian stock market average returns, volatility is reduced after Indian unblocked its stock market to Foreign Investors.

(Rai \& Bhanumurthy, 2004) Examined the role of return, risk and inflation as a determinants of foreign institutional investors for India and founded that FII inflow depends on stock market returns, inflation rates (both domestically and foreign) and ex-ante risk. In terms of magnitude, the impact of market returns and the ex-ante risk is the major determinants of FII inflow. And also found that there is any causative link running from FII inflow to stock returns. And in the last, have suggested that the stabilizing the stock market volatility and minimizing the ex-ante risk would help to attract more FII, an inflow of which have positive impact on the real economy

(Loomba, 2012) Seen the impact of FII's activity on the volatility Indian stock market by applying the Pearson correlation on daily stock price data collected from BSE for the period 01st Jan 2001 to 31st Dec 2011.This research concluded that, FIIs are strong forces driving the Indian Stock Market and mostly whenever stock market has crashed it was because of their net selling. 
(M.S.Ramaratnam, 2013) Examined the inter-linkage between the net FII investment and stock market volatility by applying the linear regression model on the data collected from BSE Official Site and SEBI for the period of three years 2010, 2011\& 2012.This study found that there is significant impact of FIIs on the BSE-Sensex and the relationship between the variables of FII investment differs in terms of their investment pattern in debt as well as in equity.

(Ashwani \& Kumar, 2014) has shown the Impact of FII on Stock Market in India by Checking the association between these two on yearly, monthly and weekly basis by applying Chi-square test on the data collected from 1993-2013. The paper's findings were that FIIs and Indian stock Market is highly correlated in longer span but there is a very less impact in the short span.

(Karan Walia, 2012) saw the relationship between the FIIs and Indian stock market by applying the Karl Pearson Correlation on the data of stocks and investments made by FIIs collected from the Websites of SEBI and BSE for the period 2001 to 2012.The paper suggests that there is a positive correlation between the foreign institutional investments and the movement of Sensex and whenever there were positive inflows from FIIs, Sensex has increased and decreased on negative inflows.

(Shrivastav, 2013) in the paper titled "Influence of FII Flows on Indian Stock Market" has seen the correlation between the FIIs and stocks of different sectors by applying statistical tools like Pearson correlation Anova etc on the data from the period 2001 to 2012. The findings were that BSE Sensex and Nifty has normal level of positive correlation with the move in FII investment, while as consumer goods and durables as well as IT sector has less impact of FII investment.

(Bansal, 2009) has shown the stock price volatility before and after the FIIs introduction in Indian Capital market by applying Wilcoxon-Mann-Whitney test, also called the rank sum test or U test on the sample data for the period 23rd January 1991 to 11th September 1992 (Total 330 trading days) and 15th September to 29th March 1994 (Total 330 trading days) BSE Index and then calculated the before and after returns. This research found that there is a great difference between returns before and after introduction of FIIs and volatility has been decreased significantly after their introduction.

(Prasanna \& Bansal, 2014)noticed the results of foreign institutional trading and influence on the market liquidity by applying methods like OLS Regression Estimates (Bi-Variate), daily log returns, F-test, Ganger test, lead effect and Multiple Regression Analysis on the data collected from the websites of NSE, CMIE \& SEBI for the period 2002-2009 the results shown FII trading effect liquidity of market in opposite direction and increase in the gross sales leads to an increase in the liquidity and gross purchases reduces the future market liquidity measured by Amihud illiquidity ratio.

(Dipankar Coondoo, 2004) Covered the sample period from January 1999 to May 2002 and measured the volatility in three aspects Strength, Duration \& Persistence (to found the volatility of stock returns, foreign equity investment and the call money rate) by applying the descriptive statistics and unit root tests .The results suggested that the strength and duration of volatility of stock market returns are more or less similar to those of the three FII flows( FII sale, FII purchase and net FII flow), volatility of the call money rate turns out to be the strongest of all the variables in terms of all three measures.

(Alzeaideen \& AL-Rawash, 2014) Examined the effect of ownership structure on share price volatility of 51 listed companies in Amman stock exchange by applying the descriptive statistics on the data collected from 2005 to 2009. The results were shown by means of two models, (OLS) model shown no significant relationship between share price volatility and ownership structure the (SUR) model shown the largest and five greatest ownership are positive but both models show that there is no significant relationship between institutional holding and stock price volatility

(Namita, 2012) has studied the flow of FII and Its Impact on Stock Market in the research the data from 1992-2011 was covered to find out volatility persistent in the Indian market after the process of financial liberalization initiated in India, FII have gained a vital role in Indian stock market. Current results have indicated a real dynamism of market and the highest peak and sudden falls. Stock market and stock prices 
of all sample indices are non-stationary and in fact integrated to each other as confirmed by the Johansson co-integration procedure.

(Singh, 2013) conducted the research to find the correlation between foreign capital flow and Indian capital market. Researcher used Karl Pearson correlation coefficient to find the associated movement between the two and a very strong positive correlation between FDI \& Sensex and FDI \& nifty, and the correlation found to be significant at 1 percent level of significance. When it comes to FII there is a moderate positive correlation between FII \& Sensex and FII \& nifty but the correlation is not significant at 1 percent level of significance.

(Srikanth, 2012) Conducted a research on the Net FII Flows into India and its Cause and Effect Study, grangers causality test to depict a relationship between inflows from FII and macro-economic variables such as WPI and IIP indicates that Economic growth is a function of, among other things, capital formation. Portfolio inflows from FIIs inject global liquidity into capital markets and raise the price-toearnings ratios, thereby reducing the cost of capital. Further issues of equity capital and stimulates investment growth in the host economy apart from bringing in best corporate governance practices. FII inflows offer dual benefits, i.e., they are a source of capital flow, without any debt component, into the economy and the exchange rate risk is borne by the foreign investor. Yet, FIIs have been targets of criticism for characteristics such as return chasing and herd behavior; hot money inflows; short-term, speculative gains; and their influence on domestic policy-making.

(Sias, 1996) Author proposes that any Increase in relative institutional holdings precedes an increase in relative volatility. Empirical results are consistent with the hypothesis that an increase in institutional investor interest induces an increase in volatility. as per the research there is a very weak relation between stock market volatility and institutional holdings. There is evidence that an increase in relative institutional holdings precedes an increase in relative volatility.

(Bushee, 1999) According to the research when any company improves the quality of its stock related disclosure improvements in disclosure quality are shown to produce contemporaneous increases in ownership mainly by institutions. These institutions can be characterized as having a short-term investment goal along with a propensity to trade aggressively. The findings reveal that the firms those with disclosure quality improvements result in a higher transient institutional investor ownership experience subsequent increases in stock return volatility.

\section{Need of study}

A lot of researches have been conducted to look at the relationship between the institutional holding patterns and the stock market volatility. The researchers have been trying to justify a relationship between the volatility and the FII holding pattern in the particular stock but they have failed to create any clear relationship between the stock market volatility and institutional holding pattern i.e. which among them is the cause and which one is the effect. The target of this research is to find out whether volatility is a random phenomenon or institutional holding play a great role in unleashing it.

The research will be useful for the institutional investors, finance institutes, brokerage firms and portfolio management firms.

\section{Objectives}

- To see the sector wise impact of institutional holding pattern on stock volatility.

- To identify the relationship between stock market volatility and institutional holding patterns. 


\section{Research methodology}

The period of study we took ranges from 1-jan-2008 to 30- sep-2014. The data was taken quarterly basis i.e. we have covered 26 quarters. The reason for taking this much of data was to know the wide scope of any FII flow on the volatility of the market, there has to be an extensive study on the various movements in the market spread over a wider range of time period.

\section{The sample}

We have taken NSE CNX NIFTY and its six sartorial indices such as CNX REALTY, CNX BANK, CNX PHARMA, CNX FMCG, CNX IT, CNX ENERGY and total 36 companies for this study. NSE is the index having higher turnover than the BSE. Also the level of FII is more in the NSE that is the reason we have taken NSE as our sample. All the data have been taken from the NSE India website, from yahoo finance and money control. In order to achieve our objectives, we are using two variables that are as under:

Quarterly holdings (q): Quarterly institutional holding is the quarterly percentage holding and the invested capital of the FII, DI including (mutual funds, PF, insurance) as well as of owner's capital and the retail holding.

Quarterly volatility $(\sigma)$ : In order to calculate quarterly volatility we will calculate standard deviation which is given as under formula:

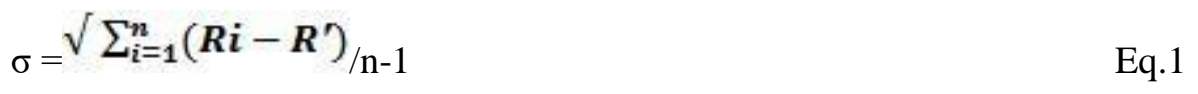

Where,

$\sigma=$ standard deviation, $\mathrm{Ri}=$ daily return, $\mathrm{i}=$ number of days, $\mathrm{R}^{\prime}=$ mean return, $\mathrm{n}=$ number of days in a quarter.

To study the impact of institutional holding pattern and stock volatility we have formed a panel data regression analysis for 36 quarters for companies of 6 different sectors.

$$
\sigma \mathrm{t}=\alpha+\beta 1(\text { FIIt-1) }+\beta 2(\text { MFt-1) }+\beta 3 \text { (Insurancet-1) } \quad \text { Eq.2 }
$$

Where,

$\alpha=$ constant, $\mathrm{t}=$ time period, $\mathrm{FII}=$ Foreign institutional investors, $\mathrm{MF}=$ Mutual funds, $\mathrm{I}=$ Insurance,

\section{DATA ANALYSIS}

Table 1: quarterly regression of all the companies from 6 different sector.

\begin{tabular}{|r|r|r|r|r|r|}
\hline Date & N & Intercept & MF & Insurance & \multicolumn{1}{|c|}{ FII } \\
\hline \multirow{2}{*}{ Mar-08 } & & & 0.132196 & -0.5077 & 0.073095 \\
& & 6.4858356 & $(.0851291)$ & $(0.37078)$ & $(0.720758)$ \\
\hline \multirow{2}{*}{ Jun-08 } & & & 0.115687 & -0.48444 & 0.08166 \\
& & 6.2568133 & $(0.087146)$ & $(0.372186)$ & $0.689275)$ \\
\hline
\end{tabular}




\begin{tabular}{|c|c|c|c|c|c|}
\hline Sep-08 & 36 & 5.6402278 & $\begin{array}{r}0.21697 \\
(0.727942)\end{array}$ & $\begin{array}{r}-0.52292 \\
(0.285898)\end{array}$ & $\begin{array}{r}0.106083 \\
(0.522129)\end{array}$ \\
\hline Dec-08 & 36 & 5.3991554 & $\begin{array}{r}0.249293 \\
(0.675694)\end{array}$ & $\begin{array}{r}-0.48805 \\
(0.310454)\end{array}$ & $\begin{array}{r}0.053972 \\
(0.741405)\end{array}$ \\
\hline Mar-09 & 36 & 5.0120342 & $\begin{array}{r}0.119276 \\
(0824024)\end{array}$ & $\begin{array}{r}-0.38593 \\
(0.388628)\end{array}$ & $\begin{array}{r}0.059396 \\
(0.713695)\end{array}$ \\
\hline Jun-09 & 36 & 4.5028953 & $\begin{array}{c}0.056203 \\
(.089622)\end{array}$ & $\begin{array}{r}-0.3061 \\
(0.388378)\end{array}$ & $\begin{array}{r}0.039392 \\
(0.777633)\end{array}$ \\
\hline Sep-09 & 36 & 3.9719941 & $\begin{array}{c}-0.04473 \\
(0.86788)\end{array}$ & $\begin{array}{r}-0.17672 \\
(0.441395)\end{array}$ & $\begin{array}{r}0.019238 \\
(0.824056)\end{array}$ \\
\hline Dec-09 & 36 & 1.9557151 & $\begin{array}{r}0.012593 \\
(0.627837)\end{array}$ & $\begin{array}{r}-0.03274 \\
(0.133932)\end{array}$ & $\begin{array}{r}0.016233 \\
(0.052753)\end{array}$ \\
\hline Mar-10 & 36 & 2.1498855 & $\begin{array}{r}0.012098 \\
(0.690676)\end{array}$ & $\begin{array}{r}-0.03374 \\
(0.160094)\end{array}$ & $\begin{array}{r}0.008707 \\
(0.322749)\end{array}$ \\
\hline Jun-10 & 36 & 2.602946 & $\begin{array}{r}-0.02882 \\
(0.438289)\end{array}$ & $\begin{array}{r}-0.05902 \\
(0.047538)\end{array}$ & $\begin{array}{r}0.000797 \\
(0.941867)\end{array}$ \\
\hline Sep-10 & 36 & 2.2349918 & $\begin{array}{r}-0.00475 \\
(0.898824)\end{array}$ & $\begin{array}{r}-0.04303 \\
(0.126234)\end{array}$ & $\begin{array}{r}0.00678 \\
(0.515596)\end{array}$ \\
\hline Dec-10 & 36 & 2.81546 & $\begin{array}{r}0.115472 \\
(0.206178)\end{array}$ & $\begin{array}{r}-0.08716 \\
(0.216873)\end{array}$ & $\begin{array}{r}-0.01529 \\
(0.517383)\end{array}$ \\
\hline Mar-11 & 36 & 0.9670067 & $\begin{array}{c}-0.02387 \\
(0.61939)\end{array}$ & $\begin{array}{r}-0.02289 \\
(0.59201)\end{array}$ & $\begin{array}{r}0.033897 \\
(0.030787)\end{array}$ \\
\hline Jun-11 & 36 & 2.1564757 & $\begin{array}{c}-0.02831 \\
(0.61452)\end{array}$ & $\begin{array}{r}-0.01786 \\
(0.698338)\end{array}$ & $\begin{array}{r}0.016139 \\
(0.308106)\end{array}$ \\
\hline Sep-11 & 36 & 2.0390667 & $\begin{array}{r}-0.0045 \\
(0.873261)\end{array}$ & $\begin{array}{r}-0.04025 \\
(0.080573)\end{array}$ & $\begin{array}{r}0.014104 \\
(0.071629)\end{array}$ \\
\hline Dec-11 & 36 & 1.6091456 & $\begin{array}{r}-0.04071 \\
(0.44971)\end{array}$ & $\begin{array}{c}0.000783 \\
(0.98495)\end{array}$ & $\begin{array}{r}0.034866 \\
(0.021201)\end{array}$ \\
\hline & & & 0.05818 & -0.03106 & -0.02604 \\
\hline
\end{tabular}




\begin{tabular}{|c|c|c|c|c|c|}
\hline Mar-12 & 36 & 1.6202441 & $(0.11327)$ & $(0.302654)$ & $(0.030956)$ \\
\hline Jun-12 & 36 & 2.282273 & $\begin{array}{r}-0.06688 \\
(0.052581)\end{array}$ & $\begin{array}{r}-0.04405 \\
(0.119115)\end{array}$ & $\begin{array}{r}0.01637 \\
(0.189226)\end{array}$ \\
\hline Sep-12 & 36 & 2.6967861 & $\begin{array}{r}-0.09520 \\
(0.024808)\end{array}$ & $\begin{array}{r}-0.05551 \\
(0.117014)\end{array}$ & $\begin{array}{r}0.01577 \\
(0.311008)\end{array}$ \\
\hline Dec-12 & 36 & 3.1145582 & $\begin{array}{c}-0.09651 \\
(.059079)\end{array}$ & $\begin{array}{r}-0.08760 \\
(0.053138)\end{array}$ & $\begin{array}{r}0.01381 \\
(0.47053)\end{array}$ \\
\hline Mar-13 & 36 & 2.1778032 & $\begin{array}{r}-0.07048 \\
(0.135338)\end{array}$ & $\begin{array}{r}-0.00389 \\
(0.927871)\end{array}$ & $\begin{array}{l}0.04132 \\
(0.0239)\end{array}$ \\
\hline Jun-13 & 36 & 1.8666855 & $\begin{array}{r}-0.01471 \\
(0.860997)\end{array}$ & $\begin{array}{r}-0.06729 \\
(0.38318)\end{array}$ & $\begin{array}{r}0.05874 \\
(0.076938)\end{array}$ \\
\hline Sep-13 & 36 & 0.6220447 & $\begin{array}{r}-0.02468 \\
(0.565754)\end{array}$ & $\begin{array}{r}-0.01651 \\
(0.668707)\end{array}$ & $\begin{array}{r}0.05802 \\
(0.001372)\end{array}$ \\
\hline Dec-13 & 36 & 2.1650581 & $\begin{array}{r}-0.05197 \\
(0.189369)\end{array}$ & $\begin{array}{c}-0.00765 \\
(0.82081)\end{array}$ & $\begin{array}{r}0.02014 \\
(0.194544)\end{array}$ \\
\hline Mar-14 & 36 & 0.872245 & $\begin{array}{r}-0.10641 \\
(0.141709)\end{array}$ & $\begin{array}{r}0.03274 \\
(0.577945)\end{array}$ & $\begin{array}{r}0.08470 \\
(0.00173)\end{array}$ \\
\hline Jun-14 & 36 & 1.4991629 & $\begin{array}{r}-0.06402 \\
(0.503624)\end{array}$ & $\begin{array}{r}0.12295 \\
(0.156071)\end{array}$ & $\begin{array}{r}0.03730 \\
(0.285856)\end{array}$ \\
\hline
\end{tabular}

It can be observed from the above table that the impact of Mutual Fund (MF) holdings on stock return volatility has been negative for 16 quarters and positive for 10 quarters out of total 26 quarters studied. This implies that the average impact of mutual fund holdings on return volatility is negative. The coefficients were only significant for two quarters which have negative impact on volatility all other quarters coefficients were insignificant.

In case of insurance institutions holding pattern, the impact on volatility was negative for the 23 quarters and positive for only three quarters, therefore the average impact of Insurance holding pattern on return volatility has been negative. Out of all the negatively effecting quarters' only one quarter coefficient was significant while as all the rest quarter coefficients were insignificant.

The holding pattern of Foreign Institutional Investors (FIIs) has positive impact on volatility in 24 quarters and for 2 quarters the impact is negative, the coefficients are significant for 6 quarters in which 5 quarters have positive impact on volatility and 1 quarter is having negative impact. Therefore FIIs holding pattern is the only variable which has shown positive impact on the stock return volatility. 
Mutual funds and insurance company have negative effect on the volatility of the stock which implies that increase in holding of insurance company and mutual fund decrease the volatility of company and viceversa.

On the other hand foreign institutional investors have positive effect on the volatility of stock which implies that increase in holding pattern of FIIs increase the volatility of company and vice-versa.

\section{Conclusion}

The Foreign Institutional Investors (FIIs) have emerged as prominent investors in the Indian stock market and their growing involvement adds as an important feature of the development of stock markets in India. Because of this, the Indian Stock Markets have reached new heights and became more volatile making the researches work in this dimension of establishing the link between FIIs and Stock Market volatility. This research paper has found out that the nature of relationship between the FII holding and the price volatility of the stock as well as the effect of the FII holdings on the volatility of the different industries in general.

This paper have provided the overview of the effect of ownership structure different institutes on stock price and will help managers and investors to have insight into the nature of ownership structure and its influence on firm's risk and the stock's return.

It has also been found out that in majority cases the significance of the institution holding pattern don't significantly affect the stock price volatility or the return except in case of FII, this means only FII is capable of investing that large bulk of capital in the stock market which can affect the volatility in the stock market.

\section{References}

Agrawal, R. N. (1997). Foreign Portfolio Investment In Some Developing Countries: A Study of Determinants and Macroeconomic Impact. Indian Economic Review , 32 (2), 217-229.

Alzeaideen, K. A., \& AL-Rawash, S. Z. (2014). The Effect of Ownership Structure on Share Price Volatility of Listed Companies in Amman Stock Exchange. Research Journal of Finance and Accounting , 5 (6).

Ashwani, A., \& Kumar, M. (2014). Impact of FII on Stock Market in India. Global Journal of Finance and Management , 765-770.

Bansal, A. (2009). Foreign institutional investor's impact on stock prices in India. Journal of Academic Reearch in Economics , 181-200.

Bansal, A., \& Pasrischa, J. S. (2009). Foreign Institutional Investors Impact on Stock Prices in India. Journal of Academic Research in Economics , 181-189.

Coondoo, Dipankar, Mukherjee, \& Pramita. (2003). Volatility of FII in India. ICRA Bulletin Money \& Finance, 85-102.

Dahlquist, M., Pinkowitz, L., Stulz, R. M., \& Williamson, R. (2003). Corporate Governance and the Home Bias. The Journal of Financial and Quantitative Analysis , 38 (1), 87-110.

Douma, S., George, R., \& Kabir, R. (2006). Foreign and domestic ownership, business groups, and firm performance: evidence from a large emerging market. Strategic Management Journal , 637-657.

Loomba, J. (2012). DO FIIS IMPACT VOLATILITY OF INDIAN STOCK MARKET ? International Journal of Marketing, Financial Services \& Management Research , 1 (7), 80-93. 
Mehta, D. (2009). FII Flows in India, Research on Indian Stock volatility. Emerald Group Publishing Limited, 14.

Namita, R. (2012). FII and Its Impact on Stock Market: A Study on Lead-Lag and Volatility Spillover. Asian Journal of Finance \& Accounting , 19-38.

Prasanna, K., \& Bansal, B. (2014). The determinants of foreign Institutional Investment in India and the role of risk, inflation and return. International Journal of Economics and Finance , 6 (6), 103-118.

Rai, K., \& BHANUMURTHY, N. R. (2004). Determinants of foreign institutional investment in india: the role of return, risk, and inflation. Indian Economic Review , 217-229.

Rai, K., \& Bhanumurthy, N. (2004). Role of return, risk and inflation as determinant of foreign institutional investors in India. Journal of Institutional investors , 42 (4), 479-493.

Ramaratnam, ,. M. (2013). IMPACT OF FII ON THE INDIAN STOCK WITH SPECIAL REFERENCE TO BSE-SENSEX. NATIONAL MONTHLY REFEREED JOURNAL OF RESEARCH IN COMMERCE \& MANAGEMENT , 4 (2).

Shrivastav, A. (2013). A Study of Influence of FII Flows on Indian Stock Market. GYANPRATHA ACCMAN Journal of Management , 5 (1).

Sias, R. (1996). Volatility and the Institutional Investor. Financial Analysts Journal , 13-20.

Singh, P. (2013). Foreign Capital Flow and Indian Capital : An Appraisal. International Journal of Business and Management Research , 487-492.

Srikanth, M. (2012). Net FII Flows into India: A Cause and Effect Study. ASCI Journal of Management, 107-120.

Walia, K. (2012). Impact of foreign institutional investment on stock market. International Research of Computing and Corporate Research, 1-12. 